\title{
LANDSCAPE ASSESSMENT AND COMMUNITY QOL EVALUATION USING KANSEI ENGINEERING
}

\author{
Yuki TSUCHIDO*, Hitoshi INOMO** and Wataru SHIRAKI** \\ * Graduate School of Kagawa University, 2227-20 hayashi, takamatsu-shi, Kagawa 864-2000, Japan \\ ** Faculty of Engineering Kagawa University, 2227-20 hayashi, takamatsu-shi, Kagawa 864-2000, Japan
}

\begin{abstract}
In this study, the evaluation of regional landscape is performed by residents using the Kansei Engineering method, and it is shown that the regional landscape is characterized by three Kansei factors such as "locality", "mentality" and "functionality". Further more, the residents are classified into three groups such as "high QOL", "middle QOL" and "low QOL" according to a regional QOL (Quality of Life) index proposed in this study using the Kansei Engineering method, and finally the Kansei for landscape is evaluated for each group. Based on these results, the contributed factors to QOL of residents are analyzed using by SOM (Self Organizing Map), and the difference of evaluation of landscape between the high QOL resident and the low QOL one.

Keywords : QOL (Quality of Life), SOM (Self Organizing Map), Landscape assessment
\end{abstract}

\section{1.はじめに}

高度経済成長期以降，日本では経済性優先の風潮が定着す る中，無秩序にあらゆる形態の建築物が建設され，地域の特 色ある街並みは減少した. しかし, バブル崩壊後, これまで の経済優先のまちづくりから住民の生活の質の向上を目指し たまちづくりへの転換が求められ，景観の保護と整備のあり 方が問われるようになってきた，また，少子高齢化という急 激な社会変化が見られる中，これまでの郊外への拡散型まち づくりの政策から都市中心部への集約型のまちづくりへの転 換が求められ, 地域コミュニティの在り方を再検討する過程 において様々な課題が浮き彫りになってきた。

この影響を受けて, 平成 17 年, 景観法が施行され, 全国 各地で景観の保全・改善のための景観計画の作成が行われて いる. 平成 20 年 6 月 1 日時点で, 公示済及び公示予定のも のを含め, 345 の地方公共団体が景観行政団体として位置づ けられている [1]．景観行政団体とは景観法により定義さ れる景観行政を司る行政機構である.しかし, 景観の評価は, 主観的で普遍妥当な評価が困難であるため, 地方公共団体な どの景観を規制する立場が考える理想の景観と地域住民が実 際に望んでいる景観が一致しない場合がある。地域の生活環 境を美しく快適に保つため, 住民の立場に立った景観づくり の推進が求められている.

さらに，内閣府の調査より，日本では「物質的な豊かさ」 よりも「心の豊かさ」を重視した生活を望む人が増加傾向に あり [2]，この心の豊かさの指標として QOL（Quality of Life）の考え方が重要視されている. しかし，このQOLに
関しても地域住民が求める「心の豊かさ」とは何か, どのよ うな方法で評価し，基準化するのかが明確でないという課題 が残されている。

QOL は生活の質という形のないものであり, 人の生活環 境など，多次元の要素によって決定される，景観は地域の生 活環境（空間）の質を問うものであり，QOL と密接な関係 があると考えられる．文献 [3] にはコミュニティや地域レ ベルの QOL の要因の 1 つに景観が含まれることが記述され ている。 また, 満足度の指標を取り入れた景観評価の研究も 行われている [4].

本研究では，住民の居住空間である地域を対象として，そ の景観，風景，風土に対して地域住民が抱いている思い（感 性）ならびに醸成されてきた心の豊かさ（QOL）を評価し， 地域景観ならびに地域 QOL の要因との関係を分析評価する 手法を提案する。そして，その手法を用いて景観構成要素の 変化が地域景観及び地域に及ぼす影響を評価するとともに, 地域景観ならびに地域 QOL の向上をもたらす規則性を見出 すことが，地域の景観整備に対する方針の決定における一つ の判断材料となり，より住人の側に立った景観作りが進めら れると考えられる. 具体的には, 香川県を対象地域として, まず，感性工学手法を用いて地域景観の評価及び住民個人 の地域 QOL の測定・評価を行い，地域 QOL の高い住民と 低い住民等の特徵による分類ごとの景観評価傾向を分析 し，景観に対する感性評価と地域 QOL の向上との関連性 を検討する。

なお, 本研究では全体を通じて, 香川大学生 10 名を被験 者とした。 


\section{2. 地域景観の評価}

本研究では，香川県景観形成指針［5］から香川県の景観 写真 50 枚と「景観」を形容できる感性ワード 25 対を選出 した. 各景観写真に対して5段階のSD尺度を用いて感性ワー ド 25 対の評価を行った。

図 1 に, 評価に用いた景観写真と被験者の平均得点を求 めた SD プロフィールを示す. SD プロフィールは評価対象 の景観写真 50 枚について作成されるが，ここでは一例とし て, 景観写真 11 番の結果を示す.

景観写真 11 番は栗林公園の写真である。栗林公園は観光 地であるため知名度が高い。よって, 感性ワード「象徵的な」 の評価が高いことが特徴的である.

SD 法によって得られた景観評価結果を用いて因子分析を 行い，香川県の景観に対する被験者の感性をいくつかの因子 に集約する，景観の感性評価実験における因子分析の結果を 表 1 に示す．表 1 より景観に対する評価因子として，第 1 因子：地域性，第 2 因子：心理性，第 3 因子：機能性の 3 つの因子に集約された。本実験では, 因子数 3 で累積寄与 率が 85.46 と高い数值が得られたことから，本実験は抽出さ れた 3 因子の他に有意な因子軸を残すことなく因子を識別 できた実験であると考えられる。

\section{3. 地域 QOL [3]}

“QOL” = Quality of Life（クオリティー・オブ・ライフ） とは, 「生活の質」・「人生の質」を意味し, 人々の生活を精 神的な豊かさや満足度も含めて質的にとらえる考え方であ る. 現在では, 主に, 医療分野で取り入れられ，患者の身体 の健康のみでなく心の健康も考慮した治療に役立てられてい る.この QOL の概念は, 多様な学問的背景を有しており, 人間のニーズや理想といった様々な視点から解釈されている.

QOL の測度は非常に多く開発されている. 表 2 にOL の測度と指標の分類を示す. QOL の測定は個人, 家族, コミュ ニティや地域，国といった 4 つの異なる分析レベルで測定 される，家庭レベルの QOL 測定は家族の QOL を改善する ために，国レベルの QOL 測定は国全体の人々の QOL を改
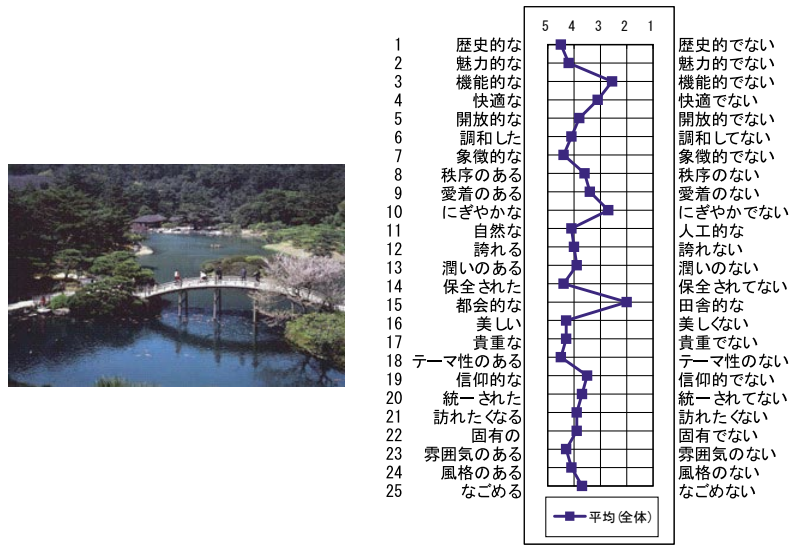

図 1 景観写真 11 番と SD プロフィール
表 1 景観の因子負荷量表

\begin{tabular}{|c|c|c|c|}
\hline & 地域性 & 心理性 & 機能性 \\
\hline 秩序のある／秩序のない & 0.87 & 0.16 & 0.02 \\
\hline テーマ性のある／テーマ性のない & 0.82 & 0.42 & -0.06 \\
\hline 象徵的な／象徵的でない & 0.80 & 0.42 & 0.00 \\
\hline 風格のある／風格のない & 0.78 & 0.35 & -0.43 \\
\hline 統一された 統一されてない & 0.78 & 0.47 & -0.09 \\
\hline 固有の／固有でない & 0.75 & 0.44 & -0.34 \\
\hline 貴重な／貴重でない & 0.74 & 0.53 & -0.32 \\
\hline 信仰的な／信仰的でない & 0.73 & -0.04 & -0.52 \\
\hline 保全された／保全されていない & 0.69 & 0.18 & 0.37 \\
\hline 誇れる／誇れない & 0.68 & 0.66 & -0.25 \\
\hline 雾囲気のある／雾囲気のない & 0.66 & 0.61 & -0.37 \\
\hline 潤いのある／潤いのない & 0.14 & 0.91 & -0.26 \\
\hline 開放的な／開放的でない & 0.14 & 0.88 & 0.03 \\
\hline 快適な／快適でない & 0.28 & 0.83 & 0.11 \\
\hline 美しい／美しくない & 0.49 & 0.80 & -0.24 \\
\hline 魅力的な／魅力的でない & 0.55 & 0.74 & -0.31 \\
\hline なごめる/なごめない & 0.47 & 0.73 & -0.42 \\
\hline 訪れたくなる／訪れたくない & 0.63 & 0.70 & -0.23 \\
\hline 調和した／調和してない & 0.47 & 0.69 & -0.36 \\
\hline 愛着のある／愛着のない & 0.53 & 0.61 & -0.20 \\
\hline 機能的な／機能的でない & -0.06 & -0.08 & 0.94 \\
\hline 都会的な／田舎的な & -0.18 & -0.19 & 0.92 \\
\hline にぎやかな/にぎやかでない & 0.01 & -0.17 & 0.75 \\
\hline 自然な／人工的な & 0.01 & 0.62 & -0.72 \\
\hline 歴史的な／歴史的でない & 0.62 & 0.03 & -0.73 \\
\hline 寄与率(\%) & 34.07 & 31.35 & 20.05 \\
\hline 累積寄与率(\%) & 34.07 & 65.41 & 85.46 \\
\hline
\end{tabular}

善するために行われる，地域を対象とした QOL は地域の全 体的 QOL と地域 QOLの2つが考えられる。前者の分析単 位は地域であり，その焦点は 1 つの社会主体としての全体 的地域の QOLに置かれている。後者の分析単位は個人であ り，その焦点は人の地域生活の領域に関連した QOLに置か れている. 本研究では後者の地域 QOL の測定・分析を行う.

また，各分析レベルでは，反射的指標か形成的指標かとい う点で概念化される. 反射的指標とは, QOL の構成概念を一 次的な存在と見なし直接的に測定される. 形成的指標は, 構 成概念が多次元で, 構成している諸次元の合成で測定される.

さらに, QOLの測定は主観的測度または客観的測度を通 じて行われる。主観的測度とはアンケートなどの自己申告形 式から測定される心理的な反応に基づいた測度である。客観 的測度は，統計データなどから測定される主観的評価を介さ ない測度である。

本研究で行う感性工学手法を用いた地域 QOL 測定は分析 レベルが個人レベルであり，形成的指標に基づく主観的測度 での測定に分類される。

表 2 QOL の測度と指標の分類

\begin{tabular}{l|c|c}
\hline & 反射的指標 & 形成的指標 \\
\hline 個人レベル & & \\
家庭レベル & 主観的測度 & 主観的測度 \\
コミユニティ·地域レベル & /客観的測度 & 客観的測度 \\
国レベル & & \\
\hline
\end{tabular}




\section{4. 感性工学手法を用いた地域 QOL 測定方法}

3 章で述べたように, QOL とは, 人々の地域における生 活の質という形のないものであり, その人の生活環境など, 多次元の要素によって決定される. また, 従来の測定方法に おいても人の感性と同様, 心理的な反応に基づいた主観的指 標によって測定されている。従って, 感性工学手法は個人の 地域 QOL の測定に適用可能と考えられる. 本研究で実施し た地域 QOL 測定は以下の（1）（4）の手順で行う.

（1）「地域」，「まち」を形容できる感性ワード 59 対を 5 段階で評価することで, 被験者の地域生活における満 足度（地域 QOL）を測定.

（2）因子分析を用いて感性ワードを $m$ 個の因子に集約 し, 地域 QOL の因子を抽出.

（3）被験者 $i$ が持つ地域 QOL の因子の得点 $f_{i j}$ を式 (1) より算出.

$$
\begin{aligned}
& f_{i j}=\sum_{k=1}^{n}\left(\frac{a_{j k}}{\sum_{k=1}^{n}\left|a_{j k}\right|} \times X_{i k}\right) \\
& \text { ここで, }
\end{aligned}
$$

$n \quad:$ 第 $j$ 因子に含まれる感性ワードの総数

$a_{j k}$ : 第 $j$ 因子における $k$ 番目の感性ワードの因子負荷量

$X_{i k}$ : 被験者 $i$ の感性ワード $k$ の評価得点

（4）被験者 $i$ の地域 QOL 得点を式（2）ょり算出.

地域 $Q O L_{i}=\sum_{j=1}^{m}\left(f_{i j} \times \frac{\text { 寄与率 }_{j}}{\text { 累積寄与率 }}\right)$

なお，この手法による QOL 測定の有効性は文献 [6] で 示されている.

\section{5. 地域 QOL の測定結果}

\section{1 因子分析による地域 QOL 因子の抽出}

因子分析を用いて，SD 法により評価されたワードをいく つかの因子に集約する. 地域 QOL 測定結果を因子分析に
よって算出された因子負荷量の結果の一部を表 3 に示す. 因子分析を行なった結果, 6つの因子が抽出された. 第 1 因 子では「機能的な/機能的でない」と「活動的な／活動的で ない」の因子負荷量が高い数值を示している。これより，第 1 因子は「利便・活動性の因子」と命名した。第 2 因子は, 「居心地の良い/居心地の悪い」「快適な／快適でない」など の感性ワードから「快適性の因子」, 第 3 因子は「安心した /安心でない」,「整備された／整備されていない」などの感 性ワードから「安全・整備性の因子」, 第 4 因子は「なごむ /なごまない」の因子負荷量がプラスの方向に高い数值を示 し,「人工的な／自然な」では因子負荷量がマイナスの方向 に高い数值を示していることから「自然性の因子」とそれぞ れ命名した，第 5 因子は「文化的な／文化的でない」，「伝 統的な／伝統的でない」という感性ワードから「文化性の因 子」, 第 6 因子は「歴史的な／歴史的でない」,「趣のある／ 趣のない」という感性ワードから「歴史性の因子」とそれぞ れ命名した。

以上, 因子分析結果から地域 QOL の因子として第 1 因子: 利便·活動性, 第 2 因子: 快適性, 第 3 因子: 安全- 整備性, 第 4 因子：自然性，第 5 因子：文化性，第 6 因子：歴史性 の 6 個の因子に集約された。これらを地域 QOL の因子とす る. 累積寄与率が 85.89 と高い数值が得られたことから, 本 実験は抽出された 6 因子の他に有意な因子軸を残すことな く因子を識別できた実験であると考えられる.

\subsection{SOM による地域 QOL の特徴分析}

因子分析により集約された 6 つの地域 QOL の因子から, 式(1)より被験者 $i$ の地域 QOL 因子に対する得点 $f_{i j}$ を式(2) より求め, 被験者 $i$ の地域 QOL 得点を算出する (図 2 参照).

地域 QOL の 6 因子の得点 $f_{i j}$ を学習データとして, 自己組 織化マップ（SOM）を用いて地域 QOL の分析を行なった. SOM は, 教師なしニューラルネットワークの一種で, その 主な特徵は, 人の感性のような非線形で多次元の評価軸を有 する入力データを低次元マップ (本研究では 2 次元マップ) で表現可能な点である，さらに，分類基準を特定したマップ （ラベリング図）を作成することにより，解析に使用する各

\begin{tabular}{|c|c|c|c|c|c|c|c|}
\hline & & 利便·活動 & 快適 & 安全·整備 & 自然 & 文化 & 歴史 \\
\hline \multirow{2}{*}{ 機能的な／機能的でない活動的な／活動的でない } & & 0.9235 & 0.0300 & 0.2225 & 0.0893 & 0.1148 & -0.2229 \\
\hline & 等 & 0.7799 & -0.1738 & 0.0374 & 0.1876 & 0.4505 & -0.1961 \\
\hline \multirow{2}{*}{ 居心地のよい／居心地が悪い快適な／快適でない } & & -0.1935 & 0.8801 & -0.1874 & 0.0235 & -0.2090 & -0.1792 \\
\hline & 等 & 0.0198 & 0.7806 & 0.4109 & 0.2484 & 0.1460 & 0.2212 \\
\hline \multirow{2}{*}{ 安心な／安心でない整備された／整備されていない } & & -0.3016 & 0.4233 & 0.7307 & 0.1377 & 0.0723 & -0.4130 \\
\hline & 等 & 0.2522 & -0.2966 & 0.7242 & -0.2029 & -0.3947 & 0.0860 \\
\hline \multirow{2}{*}{ なごむ／なごまない人工的な／自然な } & & -0.1752 & 0.3275 & -0.1780 & 0.8569 & -0.2133 & 0.0619 \\
\hline & 等 & 0.4074 & -0.1503 & -0.1298 & -0.7756 & 0.0124 & 0.1301 \\
\hline \multirow{2}{*}{ 文化的な／文化的でない伝統的な／伝統的でない } & & 0.1492 & -0.1515 & -0.0944 & -0.2567 & 0.8667 & 0.0265 \\
\hline & 等 & -0.0305 & 0.1088 & -0.1291 & -0.0349 & 0.8434 & 0.3537 \\
\hline \multirow{2}{*}{ 歴史的な／歴史的でない趣のある／趣のない } & & -0.2140 & 0.0845 & -0.1496 & 0.0084 & -0.2478 & 0.7983 \\
\hline & 等 & -0.0477 & 0.3645 & 0.1849 & -0.1811 & 0.2199 & 0.7848 \\
\hline 寄与率 (\%) & & 26.31041 & 19.94121 & 10.5728 & 10.38936 & 9.51718 & 9.162522 \\
\hline 累積寄与率（\%） & & 26.31041 & 46.25163 & 56.82443 & 67.21379 & 76.73097 & 85.89349 \\
\hline
\end{tabular}

表 3 地域 QOL 因子負荷量表 


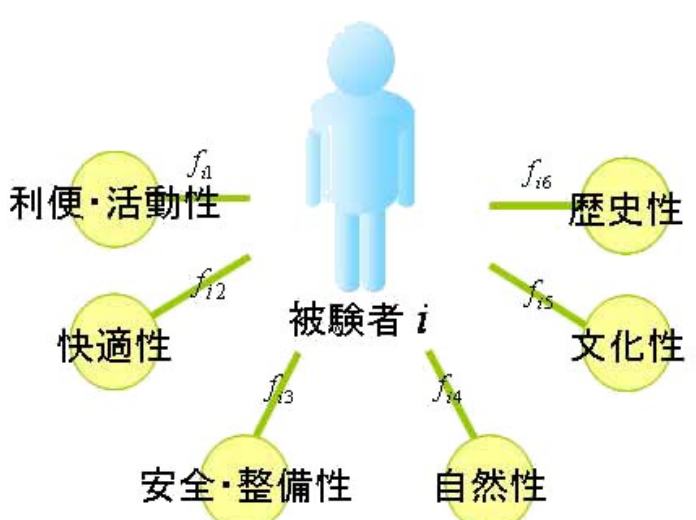

図 2 被験者が持つ地位 QOL 因子に対する得点

入力データと特定した分類基準との関連性の把握が可能と なる。

地域の住民の QOL の特徵を把握するために, クラスター 分析結果のラベリング図と学習データの重みマップの比較検 討を行った。なお，重みは図 3 に示すように重みが大きい 方を濃色，重みが小さい方を白色で表示している.

図4 にクラスター分析結果をラベリングした図を示す。 ラベリングとは, 学習データと異なる分類基準を与えて特徵 マップに表すことである。また，図 5 に利便・活動性因子 の重み, 図 6 に快適性因子の重み, 図 7 に安全・整備性因 子の重み, 図 8 に自然性因子の重み, 図 9 に文化性因子の 重み, 図 10 に歴史性因子の重みのマップをそれぞれ示す. なお，図中の数字は被験者番号である.

図 4 より，被験者を 3 つのグループに分類できることが 分かる. グループ(1)が 2 番, 4 番の被験者, グループ(2)が 3 番,

小さい 大きい

図 3 重みのランク

(2)

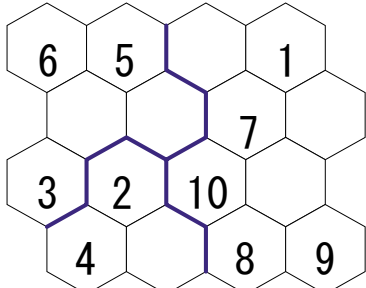

(1)

図 4 クラスター分析結果を用いたラベリングマップ

(2)

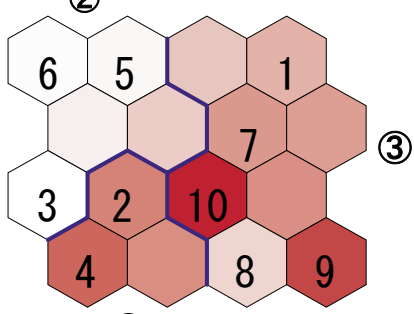

(1)

図 5 利便・活動性の重みマップ
(2)

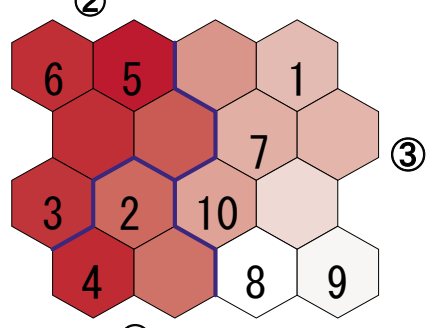

(1)

図 6 快適性の重みマップ

(2)

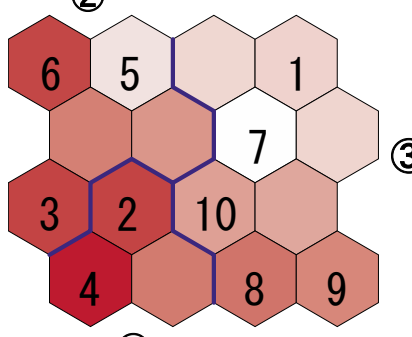

(1)

図 7 安全·整備性の重みマップ

(2)

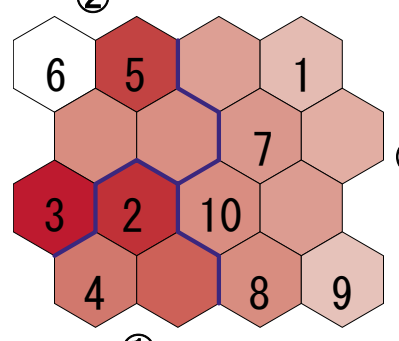

(1)

図 8 自然の重みマップ

(2)

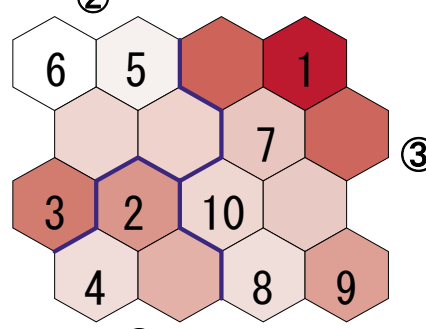

(1)

図 9 文化性の重みマップ

(2)

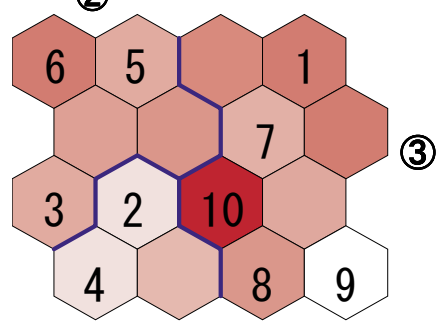

(1)

図 10 歴史性の重みマップ 
5 番, 6 番の被験者, グループ(3)が 1 番, 7 番, 8 番, 9 番, 10 番の被験者である. 分類したグループの特徵を把握する ため, 図 5 〜図 10 に示す各因子の重みを比較した結果を表 4 にまとめる.

表 4 より, グループ(1)は第 1 因子の利便・活動性や第 2 因子の快適性等の寄与率が高い因子に高い得点を有している のに対して, 第 6 因子の歴史性という寄与率が低い因子に 低い得点を有する被験者が配置されている。グループ(2)は寄 与率が高い第 1 因子の利便・活動性の因子得点は低いが,

第 2 因子の快適性には高い得点を有する被験者が配置され ている.グループ(3は寄与率が高い第 1 因子の利便・活動 性の因子得点が高く, 第 5 因子の文化性と第 6 因子の歴史 性という寄与率が低い因子に高い得点を有する被験者が配置 されている.

さらに，地域 QOL 得点を用いてラベリングしたマップを 図 11 示す。 なお, 図 3 に示す重みのランク同様, 得点が高 いほど濃色で表示している。

図 11 より,マップの左下に配置されている2 番, 4 番, 10 番の被験者は地域 QOL 得点が高く, 1 番, 8 番の被験者 は地域 QOL 得点が低いことが分かる.10 番の被験者は地 域 QOL 得点が高いが, グループ(1)ではなくグループ(3)に属 している.これは， 2 番・4 番の被験者は地域 QOL の歴史 性因子の得点が低いのに対して, 10 番の被験者はその得点 が高かったためであると考えられる。

\section{6. 地域 QOL に基づく景観評価}

地域 QOL を考慮した景観づくりを行うために, 地域住民 が居住地域の景観に対する感性を調査し, 地域 QOL の高い 人, あるいは低い人に関係する要因を探る.

まず，地域 QOL 得点の高低で被験者を分類する. 図 11 より, 被験者を地域 QOL 得点が高い被験者のグループ（被 験者:2，4，10）と地域 QOL 得点が低いグループ（被験者：

\section{表 4 グループの特徵}

\begin{tabular}{|c|c|c|c|c|c|c|}
\hline グループ & $\begin{array}{c}\text { 利便 } \\
\text { 活動 }\end{array}$ & 快適 & $\begin{array}{c}\text { 安全· } \\
\text { 整備 }\end{array}$ & 自然 & 文化 & 歴史 \\
\hline (1) & 0 & 0 & 0 & 0 & & $x$ \\
\hline (2) & $\times$ & 0 & 0 & & $x$ & \\
\hline (3) & 0 & $x$ & & & 0 & 0 \\
\hline
\end{tabular}

(2)

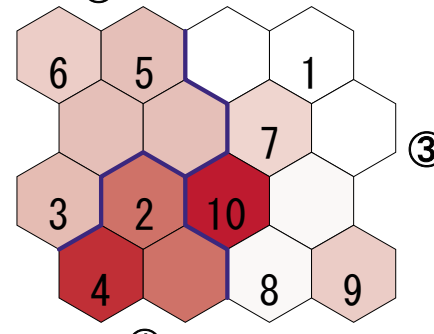

(1)

図 11 地域 QOL を用いたラベリングマップ

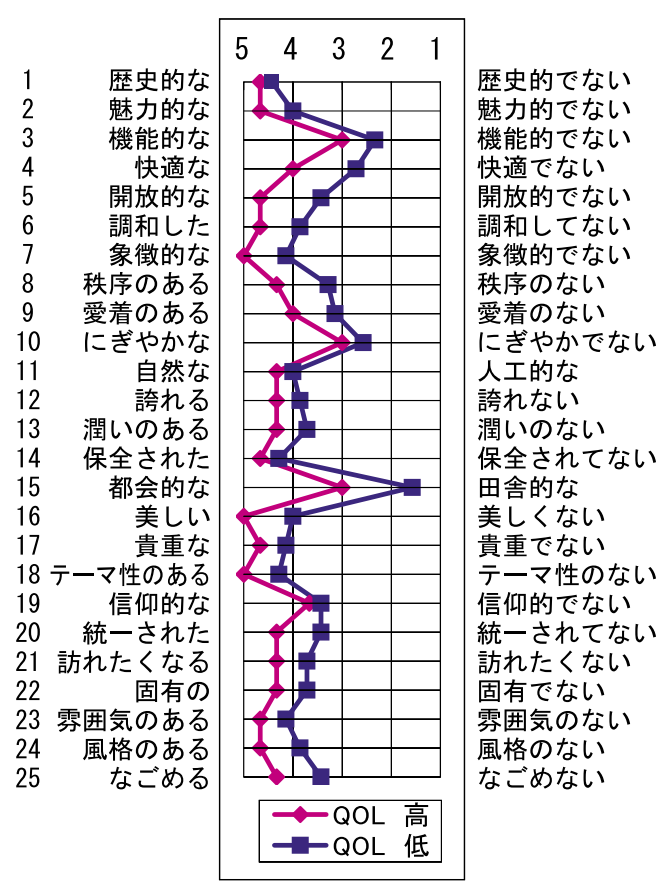

図 12 景観写真 11 番の SD プロフィール

2，4，10 以外）の 2 グループに分類し，各グループの景観 に対する感性分析を行う，景観写真 11 において各グループ の平均得点を求めた SD プロフィールを図 12 に示す.

図 12 より, 景観写真 11 番に対しては, 地域 QOL の評価 の高い被験者は, 景観評価の因子分析における “地域性（第 1 因子)”の「象徽的な」,「テーマ性のある」,「風格のある」, 「貴重な」,「保然された」“心理性（第 2 因子）”の「美しい」 「魅力的な」,「開放的な」,「潤いのある」の感性ワードに対 し高い評価を行っている。 また, 地域 QOL が低い被験者よ りも地域 QOL が高い被験者の方が感性ワードに対して高い （左寄り）の評価をしており, “地域性（第 1 因子）”の「象 徵的な」, “心理性（第 2 因子）”の「快適な」,「美しい」, ” 機能性（第 3 因子）の「都会的な」“の感性ワードにおいて, 地域 QOL の高低において差が見られることが分かる.

さらに，景観感性評価に用いた 50 枚の景観写真を香川県 景観形成指針 [5］に従い, 自然の景観, 歴史的な景観, 都市・ 集落の景観, 文化的な景観の 4 タイプに分類する. 分類し た結果を表 5 に示す.

なお, 表 5 より, 景観写真 24 番は自然の景観と歴史的な 景観, 景観写真 25 番は歴史的な景観と都市・集落の景観, 景観写真 26 番は自然の景観と都市・集落の景観, 景観写真 27 番は自然の景観と文化的な景観で重複している。

図 13 に自然の景観, 図 14 に歴史的な景観, 図 15 に都市・

表 5 景観写真の分類

\begin{tabular}{|c|c|}
\hline 景観のタイプ & \multicolumn{1}{|c|}{ 景観写真番号 } \\
\hline \hline 自然の景観 & $1,7,8,9,10,24,26,27,28,29,30,31,40$ \\
\hline 歴史的な景観 & $2,3,11,12,13,24,25,32,33,41,43,47$ \\
\hline 都市·集落の & $4,5,14,15,16,17,18,19,20,25,26,34$, \\
景観 & $35,36,37,44,46,48,49$ \\
\hline 文化的な景観 & $6,21,22,23,27,38,39,42,45,50$ \\
\hline
\end{tabular}


集落の景観, 図 16 に文化的な景観に対する各グループの評 価平均得点の SD プロフィールを示す.

図 13 の自然の景観では「機能的でない」,「開放的な」,「に ぎやかでない」，「自然な」，「田舎的な」といったワードの評 価が高くなる。図 14 の歴史的な景観では「歴史的な」,「象 徵的な」,「雲囲気のある」といったワードで評価が高い. 図 15 は平均的な評価が多い. 図 16 は歴史的な景観と評価が類 似している，また，景観の各タイプにおいて，ほとんどの感 性ワードで地域 QOL 得点が低い被験者よりも, 地域 QOL 得点が高い被験者の方が景観の感性ワードに対して左寄りの 評価をしていることが分かる.

図 13 より，香川県の自然の景観に対して，「開放的な 開放的でない」,「象徵的な／象徵的でない」,「誇れる／誇れ
ない」,「潤いのある／潤いのない」の感性ワードで評価に差 が生じている，地域 QOL の高低で評価に差が生じるという 理由から, 評価に差が生じる感性ワードに対して地域 QOL 高得点者が評価を行う方向に評価が行われるように景観整備 を行うことが地域 QOL の向上に繋がると考えられる，つま り，自然の景観では「開放的な」，「象徵的な」，「誇れる」，「潤 いのある」の感性ワードに対して高い評価が行われるよう に景観整備を行うことが地域 QOL の向上に繋がると考え られる。

同様に, 図 14 より, 歴史的な景観では「象徵的な」「秩 序のある」「誇れる」, 図 15 より, 都市·集落の景観では「開 放的な」「保全された」, 図 16 より, 文化的な景観では「象 徵的な」「誇れる」をいった感性ワードに対して高い評価が

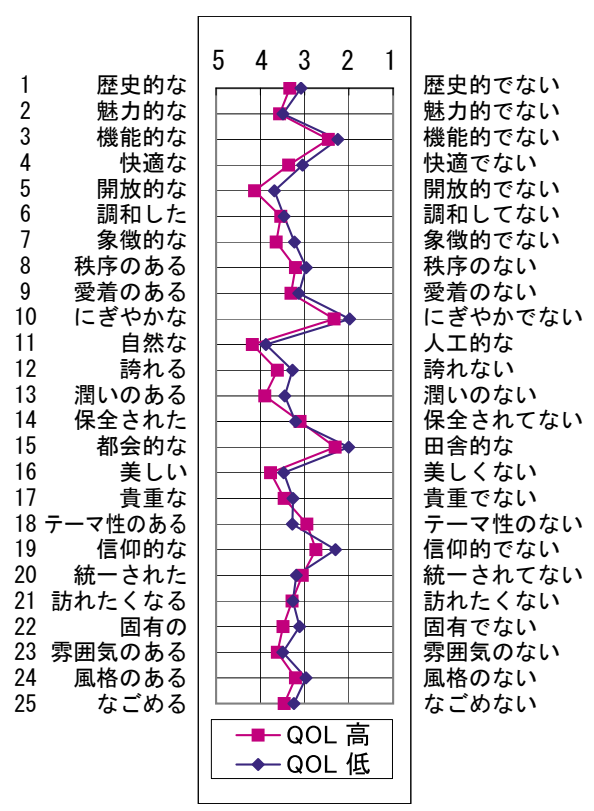

図 13 自然の景観に対する SD プロフィール

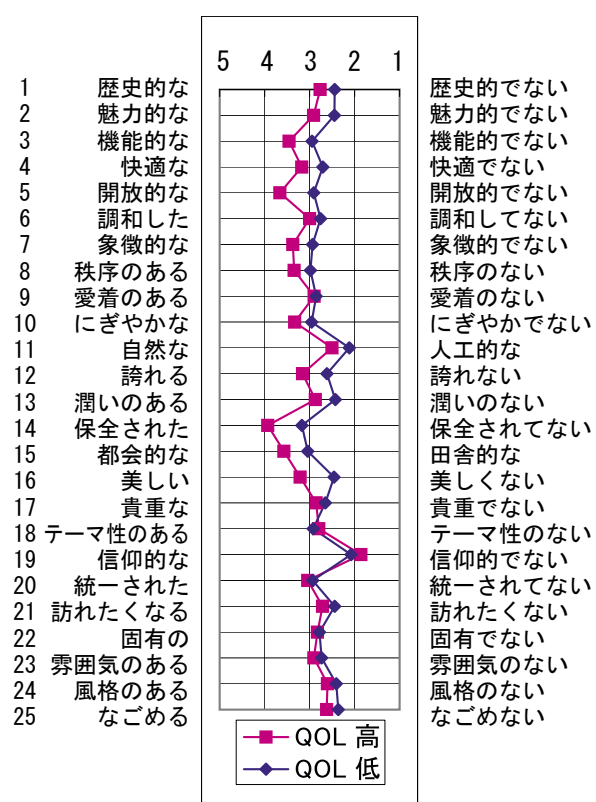

図 15 都市・集落の景観に対する SD プロフィール

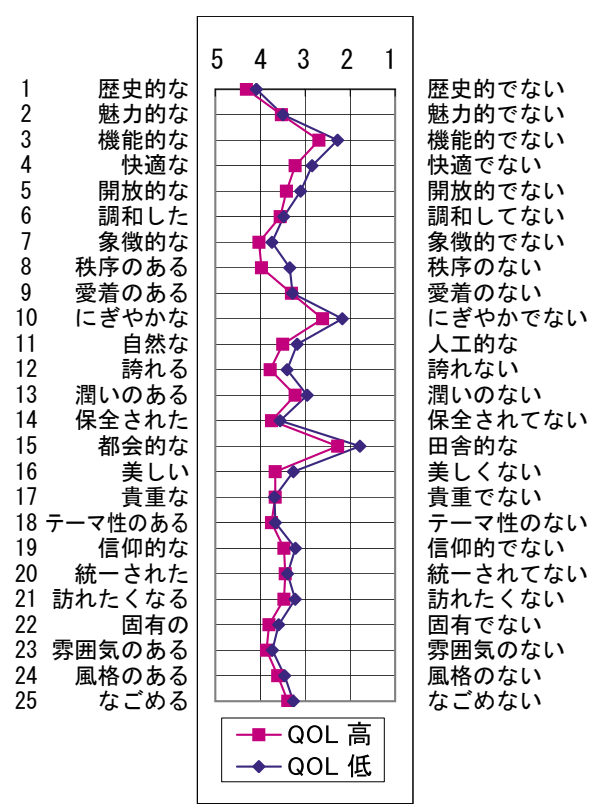

図 14 歴史的な景観に対する SD プロフィール

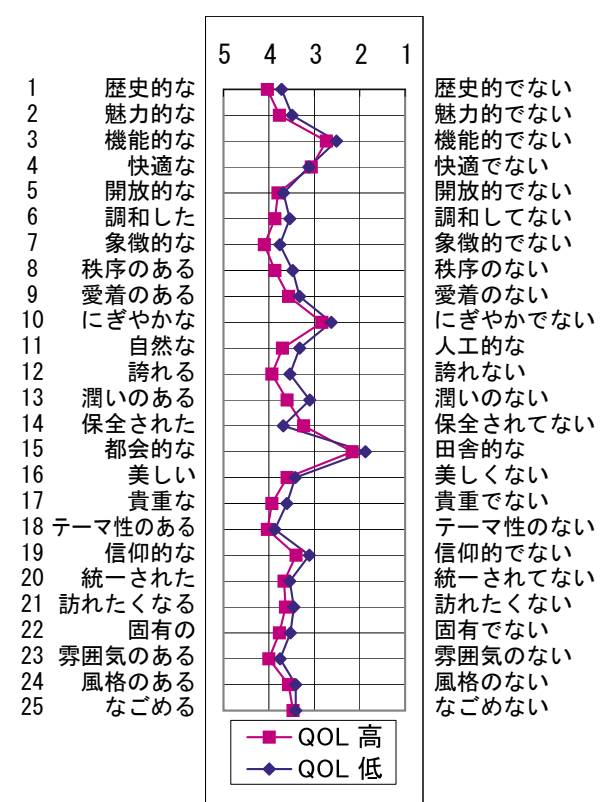

図 16 文化的な景観に対する SD プロフィール 
行われるように景観整備を行うことが地域 QOL の向上に繋 がると考えられる.

次に, クラスター分析結果で被験者を分類する. 図 4 よ り被験者をグループ1) [被験者 2，4，，グループ(2) [被験者 $3,5 ， 6]$, グループ(3) [1，7，8，9，10］に分類し, 景観 写真 11 番に拈いて, 各グループの平均得点を求めた $\mathrm{SD} フ ゚$ ロフィールを図 17 に示す.

図 17 より, 景観写真 11 番に対して, 表 4 における地域 QOLの “文化”, “歴史” の因子の因子得点が高かった被験 者のグループ(3)が「歴史的な」や「信仰的な」等の歴史, 文 化を表すワードの評価に対し, 評価が一番高い事がわかる. また, 地域 QOL の “快適”, “安全·整備”の因子得点の高かっ たグループ(2) は，田舎的であると評価していることが分か る.このように, 景観評価傾向に地域 QOL との関連の伺え る点が見受けられる。

\section{7.おわりに}

本研究では, 予備実験の段階ではあるが地域 QOL 得点 の高低に基づいた景観評価傾向を分析することにより，地 域 QOL の向上に繋がる景観整備の方向性を示す方法を提 案した。

具体的には，まず，SD 法による景観評価を行い，因子分 析で景観の 3 因子（地域性, 心理性, 機能性) を抽出した。 次に, SD 法により地域 QOL の測定を行い, その結果を用 いて因子分析して地域 QOL の 6 因子（利便 - 活動性, 快適 性, 安全・整備性, 自然性, 文化性, 歴史性) を抽出した。
因子分析の結果から被験者の各因子に対する得点と地域 QOL 得点を算出し，そのデー夕を用いて SOMによる評価 を行った。 さらに, その評価結果に基づいて被験者を地域 QOL 得点の高低でグループに分類し, 各グループの景観評 価傾向を分析した結果, 地域 QOL の高得点者が本実験の景 観評価に用いた感性ワード対に対して, 左寄りの評価をして いる傾向が観察された。 また, 地域 QOL の因子と景観の因 子の関係の詳細な分析には至らなかったが, 被験者を地域 QOL の各因子に対して有する得点のタイプ別で景観評価傾 向を分析した結果, 地域 QOL との対応が伺える箇所が見つ かった。

本論文では, 被験者の数が少なく地域 QOL の因子と景観 の因子の関係の詳細な分析までは至っていないが, 地域 QOL 得点の高い人の景観に対する評価要因の分析を行い, 地域 QOL が低い人の景観に対する評価要因との比較を行う ことにより, 評価に違いがある要因に対しての景観整備を検 討することにより，地域 QOL の向上を目指した景観整備の 一つの指針とすることができると考えている.

今後の課題としては, 景観評価および地域 QOL 評価実験 に用いる感性ワードの選出の十分な検討を行うとともに, 地 域 QOL の 6 因子と景観の 3 因子の関連性について詳細な分 析を行い, 地域 QOL 向上に繋がると考えられる景観の因子 または感性ワードに対して, どのような景観構成要素が影響 力を持っているかの分析を行う必要があると考えている.

\section{参 考 文 献}

[1] http://www.mlit.go.jp/crd/city/plan/townscape/database/ gyousei/index.htm,

情報入手日:2008/07/24

[2] 内閣府: 平成 19 年度版国民生活白書, 2007.

[3] M. ジョセフ・サージー：QOL リサーチ・ハンドブック， 同友館, 2005

[4] 遠藤幸毅, 高瀬正司, 森岡秀悟, 土井健司, 杉山郁夫：道 路空間に扔ける景観評価手法に関する課題と検討, http://www.doukuu.or.jp/kousyukai/061202/061202.pdf, 情報入手日：2007/12/3

[5］香川県：「美しい香川づくり」, 香川県景観形指針, 平成 19 年 3 月

[6] H.INOMO, W.SHIRAKI, M.FUKUI, K.KAKIZAKI: A Proposal for Health-Related Quality of Life Assessment Using KANSEI Engineering, The International Conference on Kansei Engineering and Emotion Research (KEER2007), CD-ROM, 2007

図 17 景観写真 11 番の SD プロフィール 


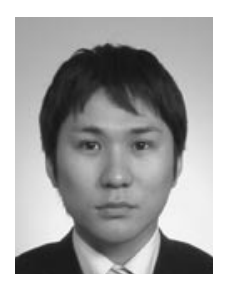

\section{土戸 祐輝（非会員）}

2008 年 3 月香川大学工学部信頼性情報シス テム工学科卒業. 同年 4 月, 香川大学大学院 工学研究科信頼性情報システム工学専攻博士 前期課程に進学, 現在に至る.

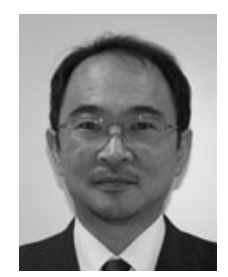

\section{井面 仁志 (正会員)}

1988 年, 愛知教育大学大学院教育学研究科 修了, 1989 年, 香川職業能力開発短期大学 校情報処理科講師, 1997 年, 香川大学工学 部創設準備室助教授, 1998 年香川大学工学 部信頼性情報システム工学科助教授, 現在に 至る. 研究分野は, 信頼性工学, 感性工学, 情報システム工学, ソフトコンピューティング. 日本材料学会, 土木学会, 日本感 性工学会, 日本人間工学会, 機械学会, PM 学会 各会員.

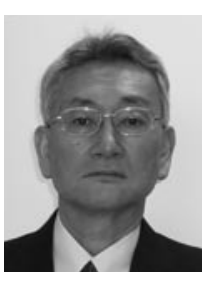

\section{白木 渡 (正会員)}

1974 年, 関西大学大学院工学研究科修士課 程修了, 1974 年, 鳥取大学工学部助手, 1980 年, 同大学講師, 1981 年, 鳥取大学工 学部助教授, 1987 ～ 1988 年, オーストリア 国インスブルック大学客員教授, 1998 年,

香川大学工学部教授に就任, 現在に至る。研究分野は, 信頼性 工学, 構造工学, 感性工学, ソフトコンピューティング等, 土 木学会, 日本材料学会, 日本感性工学会, 日本人間工学会所属. 日本感性工学会理事, 土木学会四国支部支部長, 日本材料学会 四国支部支部長を歴任. 